\title{
Research on the Design of Talent Training Mode Based on "The Ordered Class" for Certain Majors in Vocational Education
}

\author{
Huajuan Lin \\ South China University of Technology \\ Guangzhou, China
}

\author{
Wenguan Huang \\ Guangdong Overseas Chinese Vocational School \\ Guangzhou, China
}

\author{
Xiaoping $\mathrm{Hu}$ \\ South China University of Technology \\ Guangzhou, China
}

\begin{abstract}
The talent training mode based on "the ordered class" makes it possible for schools to train applied talents regarding the requirements of employees so as to avoid the blindness in talent training. With specific direction and aim, such mode is capable of achieving a "triple-win" among schools, enterprises and students. There are mainly three modes of "the ordered class": half-order mode, all-order mode and short-order mode. The construction of "the ordered class" involves the following sections: selecting cooperative enterprises as for the ordered class, constructing the teaching staff, monitoring the teaching quality, protecting rights and interests of students, evaluating students' achievement and forming a long-term mechanism on the training mode of the ordered class. However, it should be noted that: the cooperative relationship between the school and the enterprise is not too weak to reach the expected goal, and as a result, the cooperative enterprise is bearing a high risk and the school faces a high rate of resource reallocation. Therefore, the enterprise and school are supposed to consider the students as the dominant role during the cooperation and make a correct understanding and handling of the relationship of technical practice and manual labor to encourage students to make achievement in both mind and professional skills. Besides, the cooperative enterprise shall have flexible thinking and open mind to allow the students from "the ordered class" to leave after graduation for other employment opportunities.
\end{abstract}

Keywords - the ordered class; training mode; advantages; problems

\section{INTRODUCTION}

According to Planning Outline of Reform and Development of Medium-and-Long Term Education (20102020), professional education has to mobilize the initiative of enterprises. Besides, departments involved shall establish and develop a college running mechanism dominated by the government, guided by the industry and participated in by the enterprise in addition to making proper laws and regulations to facilitate accordingly to facilitate the institutionalization of college and the enterprise cooperation. Moreover, the government shall encourage organizations, enterprises to run vocational schools and entrust employee training to vocational schools. Also, departments involved shall make preferential policies to encourage enterprises to provide practice for students and students and to increase the investment on vocational education.

The talent training mode based on "the ordered class" makes it possible for schools to train applied talents regarding the requirements of employees so as to avoid the blindness in talent training because it has specific direction and aim. Such mode is likely to give students specific learning aims, arouse their initiative and enthusiasm for study to help the development of professional quality and shorten the adaptation period of students entering the enterprise; reveals the characteristics of talent training based on "cooperation of college and enterprise, combination of work and study" and realize a "triple-win" among schools, enterprises and students; graduates trained through this mode are likely to be treasured by employees as they armed themselves with not only solid professional knowledge but also strong practical ability as well as good professional quality.

\section{DISCUSSION AND ANALYSIS ON MODE}

As a link in practical teaching activity, post practice includes different types in according to requirements of different majors. The new-type talent training mode based on "the ordered class" is developed by the higher vocational education to meet the demands for talents, requiring the participation of both the enterprise and the college to make the teaching plan.

An "ordered class" is a special class made up of a certain amount of students at a higher vocational college who have passed the written examination and interview conducted by the enterprise in accordance with the its demands.

The talent training plan based on "the ordered class" is jointly made by the college and the enterprise, and over the course of making this plan, they have to consider the system integrity of the professional knowledge learned by students at 
schools and also have to take into account of the requirements of the enterprise for students' professional knowledge and overall quality. Therefore, lectures of professional knowledge for students in ordered classes are mainly given by the teaching staff at the college while lectures of professional knowledge, qualities, etc. related to the enterprise are mainly offered by the job training personnel from the enterprise.
After completing the required scores by the college and required job training by the enterprise, students are expected to perform post practice at corresponding enterprises. After acquiring the graduation certificate, students from "the ordered class" can directly sign a labor contract with the enterprise to work at that enterprise.

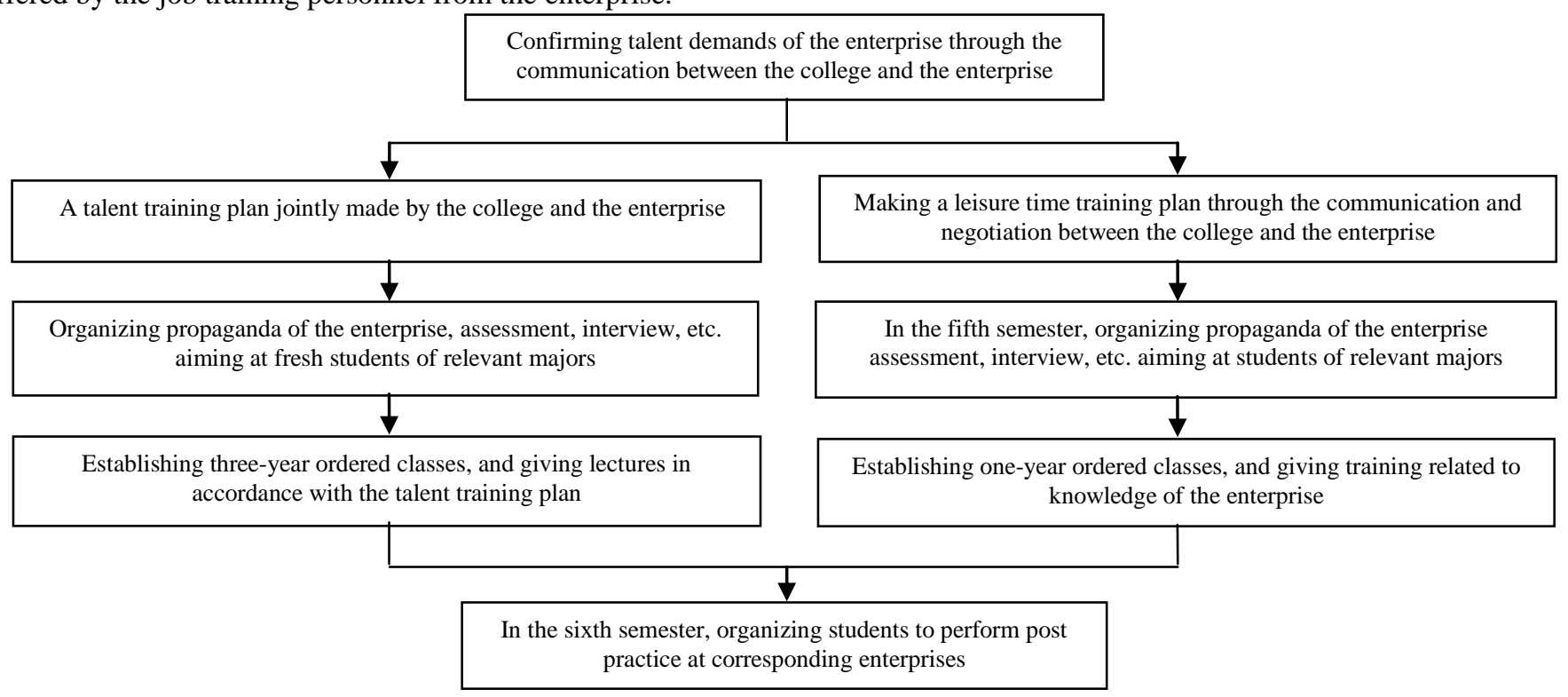

Fig. 1. The implementation process of the talent training mode based on "the ordered class".

The Ordered Class has three main modes: Half-order mode, all-order mode and short-order mode.

\section{A. Half-Order Mode.}

It refers that after students having a year of professional foundation in school, according to the cooperative enterprise's development needs, to select the students from the corresponding professional, and then to form a new class; The targeted courses shall be set on the basis of the requirements of enterprise posts; In this way, the teaching time enterprises involved is too late, leaving the enterprises and students not enough time to understand each other. Especially for the general well-known cooperative enterprises, it is difficult to bring the advantages of the Ordered Class in a short time, resulting in a large loss of students in the class when they graduate.

\section{B. All-order Mode.}

It refers that, according to their own development needs and the development trend of their industry, the cooperative enterprises plan the needs of personnel, determine the employment plan, and work with schools to formulate training programs and determine teaching plans. According to the professional knowledge of the post, to set the course, determine the examination subjects and performance evaluation methods.

This cooperating mode put forward high requirements to both of schools and enterprises. Most of all, the enterprises shall participate in the teaching level deeply, have the basic teaching ability, and be familiar with the teaching rule and each education rules and regulations. Only in this way can we form more in-depth, close and complex teaching cooperation with the school. And once successful, it will achieve higher achievement.

\section{Short-order Mode.}

This way is different from the above two ways, and the teaching is mostly for enterprise employees. It refers that the cooperation enterprise, according to the development needs and own situation, centralizes to sets the time course of one month to three months. For staff training, staff can be assigned to the school to study with the students, can also be a separate class teaching, or the school sends teachers to enterprises for teaching.

\section{How to BuILD THE MODE OF "THE ORDERED ClasS"}

\section{A. Selection of Enterprises Cooperating with the Ordered Class}

Choosing the right cooperation is the most important task of the Ordered Class in the early stage of establishment, and will directly affect the operation of the Ordered Class. As an enterprise that pursues the goal of maximizing benefits, it will first consider whether it will bring more benefits to itself if cooperating with the school to establish the Ordered Class. The school needs to know the requirements of the cooperating enterprises as so to cater to enterprises in exchange for enthusiasm. The school is the main responsibility for training students, and enterprises hope to advance the training of new staff to the students through the Ordered Class, and finish the 
study with professional knowledge at the same time, and at the same time to achieve knowledge and ability in line with job requirements, synchronization of values and corporate culture. Enterprises hope to achieve this batch of talent recruitment of low-cost, efficient and zero-distance. As for schools, have many students in the Ordered Class would like to be and intern in the cooperating enterprise when they graduated, and how many of them meet the requirement of cooperative enterprises, has become the first to focus on the issue. After defining the demand for talents, the school can consider whether or not the cooperative enterprise has the ability to jointly build the Ordered Class with reference to the results of the following questions "Table I".

\section{TABLE I. REFERENCE QUESTIONS}

\begin{tabular}{|l|l|}
\hline $\mathbf{1}$ & Does the enterprise have enough technical power? \\
\hline $\mathbf{2}$ & Is the business of the enterprise adequate and stable? \\
\hline $\mathbf{3}$ & $\begin{array}{l}\text { Is the enterprise directly organized by the deputy general manager or } \\
\text { above to organize the teaching of the Ordered Class? }\end{array}$ \\
\hline $\mathbf{4}$ & $\begin{array}{l}\text { Does the enterprise set up a special team to handle the operation of } \\
\text { the Ordered Class? }\end{array}$ \\
\hline $\mathbf{5}$ & $\begin{array}{l}\text { Does the enterprise have enough technical staff to meet the teaching } \\
\text { level? }\end{array}$ \\
\hline $\mathbf{6}$ & $\begin{array}{l}\text { Does the technician have enough time and effort to complete the } \\
\text { teaching task of the Ordered Class in the rest time of his or her work? }\end{array}$ \\
\hline $\mathbf{7}$ & $\begin{array}{l}\text { Does the enterprise has sufficient number of jobs to receive the } \\
\text { internships and employment from the Ordered Class? }\end{array}$ \\
\hline $\mathbf{8}$ & $\begin{array}{l}\text { Whether the enterprise has a number of scale, process type and } \\
\text { quantity in line with the teaching requirements of the project for } \\
\text { students to practice, training and internship? }\end{array}$ \\
\hline $\mathbf{9}$ & $\begin{array}{l}\text { Is the project available for teaching purposes a standard site and is } \\
\text { site management standardized? }\end{array}$ \\
\hline $\mathbf{1 0}$ & $\begin{array}{l}\text { Whether the project provided by the enterprise can be provided with } \\
\text { the basic teaching conditions (such as being used as the basic } \\
\text { multimedia equipment for classroom rooms and projectors)? }\end{array}$ \\
\hline $\mathbf{1 1}$ & $\begin{array}{l}\text { Is the traffic convenient between the project that the enterprise } \\
\text { provide for teaching and school? }\end{array}$ \\
\hline $\mathbf{1 2}$ & $\begin{array}{l}\text { Is there any support from other construction participants in the } \\
\text { project that the enterprise can provide to the teaching? }\end{array}$ \\
\hline
\end{tabular}

\section{B. The Construction of Teaching Staff}

The operation of the Ordered Class relies on the cooperation between the on-campus full-time teachers and the after-school part-time teachers. Compared with the more professional and stable on-campus full-time teachers, although the part-time teachers provided by cooperative enterprises are rich in practical experience, they may not be the most suitable teachers. Meanwhile, there will be objectively a lack of teaching experience, and a conflict between one's own job and teaching job which may result in temporary change of course and suspension, as well as subjectively a lack of energy in preparing lessons, inadequate attention to teaching work and so on. For the school, it unilaterally cannot restrain the above situation which may exist in the enterprise part-time teachers, so school needs to communicate with the enterprise beforehand and seek the countermeasure to eliminate such problems from the source when it prepares the Ordered Class works. At the same time, for part-time teachers, the school must realize the teaching job of the Ordered Class is not their' own work, on the contrary, the school usually thinks that the part-time teachers with higher professional ability and teaching ability are the precious talents for the enterprise and of course arrange them in their own jobs to create more value. In this environment, in order to ensure the teaching quality of the Ordered Class and give full play to the role of part-time teachers, it is necessary for both schools and enterprises to discuss thoroughly and find the balance of interests between the two sides.

\section{Teaching Quality Monitoring}

The teachers of both schools and enterprises need to record, track and analyze their learning process to obtain the feedback of teaching quality. At the same time, teaching quality monitoring shall be carried out combining with the teachers' exchange of both schools and enterprises and the discussion with students, so as to detect the deviations timely. The quality of teaching can be maintained at the expected level by rectifying deviations continuously.

\section{The Guarantee of Rights and Interests for Students}

By two aspects of insurance system and cooperation and support of cooperation, both schools and enterprises need to establish a perfect guarantee system for students' rights and interests. In addition, when the Ordered Class was running, some students voluntarily participated in the training of the Ordered Class and also were willing to sign a tripartite training agreement in the initial stage. However, when they came to the internship phase, they changed their mind to go to their favorite enterprise to do the job, therefore, they will have conflicts with the cooperative enterprises and form antipathy emotions; Or when they enter into the cooperative enterprise to do the internship, they find that there is a gap between the actual situation and their own psychological expectations and form antipathy emotions. Both schools and enterprises need to beforehand have full foresight on such problems, communicate in advance and formulate plans according to actual situation to solve them.

\section{E. Student Performance Assessment}

Previously, researchers have proposed "three mechanisms" to assess the performance of students in Ordered Class, that is, both quantitative assessment and qualitative evaluation mechanism; both ability evaluation and knowledge evaluation mechanism; both school evaluation and the enterprise assessment mechanism.

\section{F. Long-Term Mechanism of the Ordered Class Training}

The construction and management profession of the threeyear schooling system determines the period of talent training in Ordered Classes. In order to achieve the goal of accumulating experience and improving the training system, the Ordered Class of the school and enterprise needs to continuously repeat this period, therefore, the establishment of long-term mechanism between schools and enterprises is particularly important. When the schools and enterprises work together to establish the Ordered Classes, they can usually foresee the things in the next 3-5 years and maintain close cooperation. If they want to form a longer lasting mechanism, it will tend to be inadequate only relying on the ability of schools and enterprises. 


\section{ISSUES NEEDING TO BE NoticED}

- The Cooperation between Schools and Enterprises Is Not Thoroughly Enough That Is Hard to Achieve the Expected Goals. Generally speaking, for the cooperation with commercial enterprises, due to the business nature, the internship of students in such enterprises shall be relatively more thorough; however, compared with industrial enterprises, the students can only participate in the simple and basic works in such enterprises but cannot deeply understand the practical knowledge and the promotion of their professional skills, vocational ability and employability are all limited to certain extent; in addition, for those regions with underdeveloped economy, if the higher vocational colleges need to establish cooperation relationship, they need to find the cooperative enterprises first, however, in such regions, it is hard for those colleges to find suitable cooperative enterprises due to the underdeveloped industry and business. If they choose to cooperate with the enterprises in relatively developed regions along the coast (other regions), there will be problems such as transportation, accommodation and differences in customs which will impact the in-depth development of cooperation between schools and enterprises.

- Higher Risks In Signing Contracts of Enterprises. Compared with the internal training of enterprises, the enterprises need to sign contracts with schools and the individuals. Therefore, the contract risks brought by the contracts are relatively high. There will be a long period of training process from signing the order-style training contracts between school and enterprise to the final employment. During such period, the employment demands of enterprises will be changed with the industrial development. Facing those changes, the enterprises taking order-style training as the main subject need to negotiate with schools to reform courses and change the training locations and negotiate with the individuals to change the posts, etc. This series of process will delay the market response and causes the time-lag effect. At the same time, the income period will be relatively long. Compared with other types of training, although the order-style training between school and enterprise possesses relatively lower investment and higher income, its income period is relatively long.

- The Ratio of School Resource Reallocation Is Higher. The order-style training needs to combine with the speciality of enterprise posts to appropriately change the teacher structure, field layout and other resources, therefore, once the cooperation project has to be changed, the contents of skill training, teacher structure and training location layout must be adjusted which will cause higher ratio of resource reallocation. At the same time, the teachers in leading team for cooperation between higher vocational college and enterprise are getting younger and there lacks the leaders with senior professional titles and many of the part-time teachers of enterprises just have several lectures in schools which plays a little functions to the course construction and the young teachers lack the practical experience.

- In the "Ordered Class", the Subject Status of Students Shall Be Respected. For Example, The Arrangement Of Post Labor In Enterprises Of Students Shall Belong To The Reasonable Stipulation In The Teaching Plan And Shall Be Taken Into The Teaching Management Process. The "order-style" talent training is an attempt to the educational reform and significantly shows the Chinese type "dual system" of vocational education concept but shall absolutely not be the expedient for solving the labor source of enterprises. When starting the "ordered class", both school and the enterprise shall insist on the vocational talent training goals and strictly comply with the vocational education regulations and practically ensure the students to take learning as the principle.

- Correctly understand and handle the relations between technical practice and labor exercise and encourage students to strive to realize double gains of mind cultivating and professional skills.

- The cooperative enterprises shall possess flexible minds and open heart to permit the students in "ordered class" to leave the cooperative enterprises and seek for other employment channels.

\section{CONCLUSION}

In the higher vocational education, substituted post exercitation is an important practical teaching link. The training mode of "the Ordered Class" not only promotes the substituted post exercitation of students, but also can realize the win-win of cooperation between school and enterprise. Through the implementation of training model of "the Ordered Class", the school absorbs enterprises to participate in personnel training, and the advanced concept of enterprises is introduced into management and teaching, which is conducive to promoting professional construction and process reform; At the same time, the enterprise's training to employees is extended to schools from the enterprise, so as to shorten the adjustment period after induction and obtain skilled employees.

\section{REFERENCES}

[1] Dong Chunqi, Gu Jinfu, Yu Youjuan. Teaching Situation and Countermeasure Analysis on the Ordered Class in Higher Vocational Teaching Mode of " Combination of learning with working, cooperation between school and enterprise" [J]. Economic Research Guide, 2012, 9

[2] Guo Yuan. Construction of Examination and Evaluation System of the Ordered Class under the Order-type Talent Training Mode

[3] Chen Lieqiang, Zhang Zhixia, Jin Chuanwei, Tang Xinyu. Research on the Development Obstacles and Development Strategies of "Order type" Talent Training Model in Higher Vocational Education [J] Teaching Research Theory 2015.24. 